\title{
The global state of evidence on interventions to prevent child marriage
}

\author{
Sophia Chae \\ Population Council \\ Thoai Ngo \\ Population Council
}

Follow this and additional works at: https://knowledgecommons.popcouncil.org/departments_sbsr-pgy How does access to this work benefit you? Let us know!

\section{Recommended Citation}

Chae, Sophia and Thoai Ngo. 2017. "The global state of evidence on interventions to prevent child marriage," GIRL Center Research Brief no. 1. New York: Population Council. 
GIRL Center Research Brief

No. 1 October 2017

THE GLOBAL STATE

OF EVIDENCE ON

INTERVENTIONS

TO PREVENT

CHILD MARRIAGE

SOPHIA CHAE AND THOAI D. NGO

GIRL 漛Center

FOR INNOVATION, RESEARCH, AND LEARNING 
The Girl Innovation, Research, and Learning (GIRL)

Center generates, synthesizes, and translates evidence to transform the lives of adolescent girls

popcouncil.org/girlcenter

GIRL Center Research Briefs present new knowledge on issues of current and critical importance and recommend future directions for research, policies, and programs.

"The Global State of Evidence on Interventions to Prevent Child Marriage" was made possible through the generous support of the John D. and Catherine T. MacArthur Foundation, The William and Flora Hewlett Foundation, and the Mark A. Walker Fellowship Program to the Girl Innovation, Research, and Learning (GIRL) Center. We are grateful to Sajeda Amin, Annabel Erulkar, and Michelle Hindin for providing valuable comments on earlier versions of this brief.

Suggested citation: Chae, Sophia and Thoai D. Ngo. 2017. "The Global State of Evidence on Interventions to Prevent Child Marriage," GIRL Center Research Brief No. 1. New York: Population Council.

(c) 2017 The Population Council, Inc. 
GROWING RECOGNITION OF THE HARMFUL EFFECTS OF CHILD MARRIAGE HAS PLACED ITS ELIMINATION ON THE GLOBAL AND NATIONAL AGENDA. TO ADDRESS THIS PROBLEM, WE REVIEWED THE GLOBAL STATE OF EVIDENCE ON WHAT WORKS TO PREVENT CHILD MARRIAGE.

Our research focuses exclusively on rigorously evaluated interventions, defined as interventions evaluated as part of a randomized controlled trial (RCT), quasi-experimental study, or a natural experiment, and incorporates new results not included in previous reviews. In total, 22 interventions across 13 low- and middle-income countries met the inclusion criteria and were included in this review.

The study documented the types of child-marriage interventions and approaches used, assessed what works best (and what does not work) to reduce child marriage, investigated the impact of interventions on other aspects of girls' well-being, and reported the costs of implementing these interventions.

\section{OUR FINDINGS SUGGEST THAT INTERVENTIONS} INCORPORATING AN EMPOWERMENT APPROACH, EITHER AS THE SOLE APPROACH OR IN CONJUNCTION WITH ANOTHER APPROACH, DEMONSTRATED THE GREATEST SUCCESS IN REDUCING CHILD MARRIAGE.

Compared to prior reviews, we observed that economic approaches were the least successful in preventing child marriage. The majority of studies included in this review also improved girls' schooling outcomes and reduced girls' risk of pregnancy/childbearing. Only a handful of studies reported the costs of implementing their respective interventions. Our study makes recommendations on how to improve the effectiveness of child-marriage interventions and the documentation and evaluation of these interventions. 
Child marriage, defined as marriage before age 18 , is a violation of human rights. Every year, 15 million girls are married as children-equating to one girl marrying every two seconds. ${ }^{1}$ Although many countries impose laws setting 18 as the minimum age of marriage, the practice of child marriage remains widespread. Globally, 720 million women alive today were married before turning 18, with one-third married before age $15 .{ }^{1}$ Child marriage is prevalent but varies widely in sub-Saharan Africa (range: 5-76\%) and South Asia (range: 4-52\%). In subSaharan Africa, around 4 in 10 girls marry by age $18 .^{2}$ Although the prevalence of child marriage is lower in South Asia, its larger population size produces a higher absolute number of married girls. As a result, two in five married girls live in South Asia, and one in three live in India. *

Many social and economic factors fuel the harmful practice of child marriage. Poverty, one of the most common drivers, pushes families to use marriage as an economic strategy to free up limited resources for the rest of the family. In contexts where the exchange of bridewealth or dowry is practiced, families may be financially motivated to marry their daughters early, and where virginity is strongly valued, parents may marry their daughters early to ensure that they remain virgins until marriage. Girls who become pregnant out of wedlock may be viewed as bringing shame and dishonor to the family. Moreover, a lack of viable alternatives could lead girls to marry early, particularly if they are not working or in school.

Child marriage marks the end of childhood and adolescence, forcing girls to assume adult roles and responsibilities even though they are not physically and emotionally ready to do so. This harmful practice can have severe repercussions for girls, their children, and their communities. Childbearing is often expected to take place soon after marriage, putting girls at risk of suffering complications or even dying during pregnancy and childbirth because their bodies are not yet fully developed. ${ }^{3-5}$ Consequently, children born to adolescent mothers experience poorer health outcomes and higher mortality rates than children born to older mothers. ${ }^{6-8}$ In addition, girls who marry before age 18 experience elevated rates of intimate partner violence compared to their peers who marry as adults (29\% vs. $20 \%$, respectively). ${ }^{9}$

Not only does child marriage produce negative consequences for girls and their children, but it also has negative effects for their families, communities, and societies. The economic impact of child marriage is significant. For example, global GDP could be $\$ 4$ trillion higher for the period 2014 to 2030 if child marriage was eliminated. ${ }^{10}$ Thus, child marriage perpetuates the cycle of poverty that exists in low- and middle-income countries.

* Countries that set age 18 as the legal minimum age of marriage but permit exceptions under the law (e.g., with parental or judicial consent) were not considered to have laws banning child marriage. Since the publication of these data, five countries (Bangladesh, Gambia, Kenya, Malawi, Tanzania) have passed legislation modifying their legal minimum age of marriage. The current statistic reflects these recent changes. 
Due to the harmful effects of child marriage, eliminating it has become a greater priority on the global and national agenda. Goal 5 of the Sustainable Development Goals calls for the eradication of child marriage. In South Asia, $38 \%$ of countries have deployed laws banning child marriage, and in sub-Saharan Africa, $46 \%$ have done so. ${ }^{11}$ Still, to be effective, laws and policies need to be coupled with evidencebased programs/interventions that deliver resources into communities where child marriage remains prevalent.

Whereas the prevalence of child marriage has declined since the early 1980s, the numbers of girls marrying before age 18 has risen due to the sheer size of the current cohort of adolescent girls - the largest in history. ${ }^{12}$ Over the past two decades, policymakers and program planners have implemented policies and programs to eliminate this harmful practice. A 2007 study identified 66 childmarriage interventions that had been implemented across 30 countries. ${ }^{13}$ Since then, many more interventions have been implemented. Yet there needs to be accelerated effort in using high-quality evidence on what works (and what does not work) to better direct investment in programs that aim to eliminate child marriage.

In recent years, several attempts have been made to review and assess the effectiveness of child-marriage interventions. ${ }^{14-17}$ The conclusions reached in these studies have been mixed-two studies found empowerment to be the most effective approach, while the other two studies found economic approaches to be more effective. This research brief exclusively reviews evidence from rigorously evaluated interventions conducted over the past 20 years and builds on previous reviews by incorporating new results.

The main objectives of this review are to:

\begin{tabular}{|c|c|c|}
\hline $\begin{array}{l}\text { Describe the types of } \\
\text { interventions that have } \\
\text { been implemented }\end{array}$ & $\begin{array}{l}\text { Describe the } \\
\text { approaches used in } \\
\text { these interventions }\end{array}$ & $\begin{array}{l}\text { Assess which interventions } \\
\text { are effective and which are } \\
\text { ineffective }\end{array}$ \\
\hline $\begin{array}{l}\text { Investigate the impact } \\
\text { of interventions on other } \\
\text { aspects of girls' well-being }\end{array}$ & $\begin{array}{l}\text { Report the costs of } \\
\text { implementing these } \\
\text { interventions }\end{array}$ & $\begin{array}{l}\text { Make recommendations } \\
\text { for future child-marriage } \\
\text { interventions }\end{array}$ \\
\hline
\end{tabular}




\section{METHODOLOGY}

Our review included all studies that examined the impact of interventions on child marriage, regardless of whether the intervention was designed to reduce child marriage or to improve other aspects of adolescent well-being such as schooling and health.

- We restricted our review to the most rigorously evaluated interventions, defined as interventions evaluated as part of an RCT, quasiexperimental study, or a natural experiment. By the nature of the study design, these evaluations included both a control group as well as baseline and endline data.

- We also limited our review to studies that measured the prevalence of child marriage and/or the age at first marriage, either in the study population or the community, and excluded studies that only measured knowledge and/or attitudes toward child marriage.

- We only considered interventions that were implemented over the past 20 years, since 1997. Interventions that were implemented before 1997 but were still in progress in 1997 were eligible to be included in this study.

We searched for peer-reviewed and non-peer-reviewed published studies that met our inclusion criteria. We first considered 30 studies that were included in recently published reviews. ${ }^{14-17}$ Sixteen of these studies met the criteria to be included in our review; the other 14 studies were excluded because they did not meet our criteria for rigorous evaluations. Next, we searched scholarly databases (e.g., Web of Science, Google Scholar, PubMed) and the internet for additional studies that were not included in prior reviews or were available after the reviews were published. We identified an additional 7 studies, of which 6 met the criteria to be included in our review.

In total, 22 studies met our inclusion criteria: 9 RCTs, 9 quasi-experimental studies, and 4 natural experiments. These studies cover 13 countries: Bangladesh (5), Burkina Faso, Colombia, Ethiopia, India (4), Kenya (2), Malawi, Mexico, Nepal, Pakistan, Tanzania (2), Uganda, and Zimbabwe. From each study, we extracted key information, including study setting, year(s), evaluation design, type of intervention, components, approaches used, and other outcomes examined and their impact (see Appendix).

We utilized this information to examine the types of interventions and approaches used, and to assess what works best (and what does not work) to reduce child marriage. We also investigated the impact of child-marriage interventions on girls' schooling and pregnancy/childbearing outcomes due to their influence on the present and future lives of adolescent girls. Finally, we reported costing information (where available) for the interventions in our study. 


\section{FINDINGS}

\section{TYPES OF INTERVENTIONS}

We grouped interventions into three categories based on how they were implemented and evaluated.

1. The first category "single interventions" consists of 11 interventions with a single component (e.g., conditional cash transfer) that was implemented and evaluated against a control arm.

2. The second category "single intervention with multiple components" comprises 6 interventions each having multiple components. Rather than the individual components being evaluated, the intervention was evaluated as a whole compared to a control arm. Berhane Hewan, implemented in Ethiopia, is an example of a single intervention comprised of multiple components: social mobilization and group formation by adult female mentors; participation in nonformal education and livelihoods training for out-of-school girls or support to remain in school; a conditional asset transfer (goat); and community conversations. ${ }^{18}$

3. The third category "multiple component interventions" consists of 5 interventions each having multiple components; each component was implemented and evaluated separately against a control arm. For example, BALIKA in Bangladesh consisted of three components implemented separately in three different communities: education; gender-rights awareness training; and livelihoods-skills training. ${ }^{19}$

Over the past two decades, the types of interventions that have been implemented and evaluated for their impact on child marriage has shifted from single to multiple components (Figure 1). While single interventions (with or without multiple components) were common through the early 2000s, multiple interventions increased in popularity starting in the mid-2000s. All the most recent studies were multiple interventions, likely reflecting growing acknowledgment of the need to evaluate intervention components separately to better assess the effectiveness of individual components at reducing child marriage. 


\section{FIGURE 1. TYPES OF CHILD MARRIAGE INTERVENTIONS BY YEAR OF}

IMPLEMENTATION

5

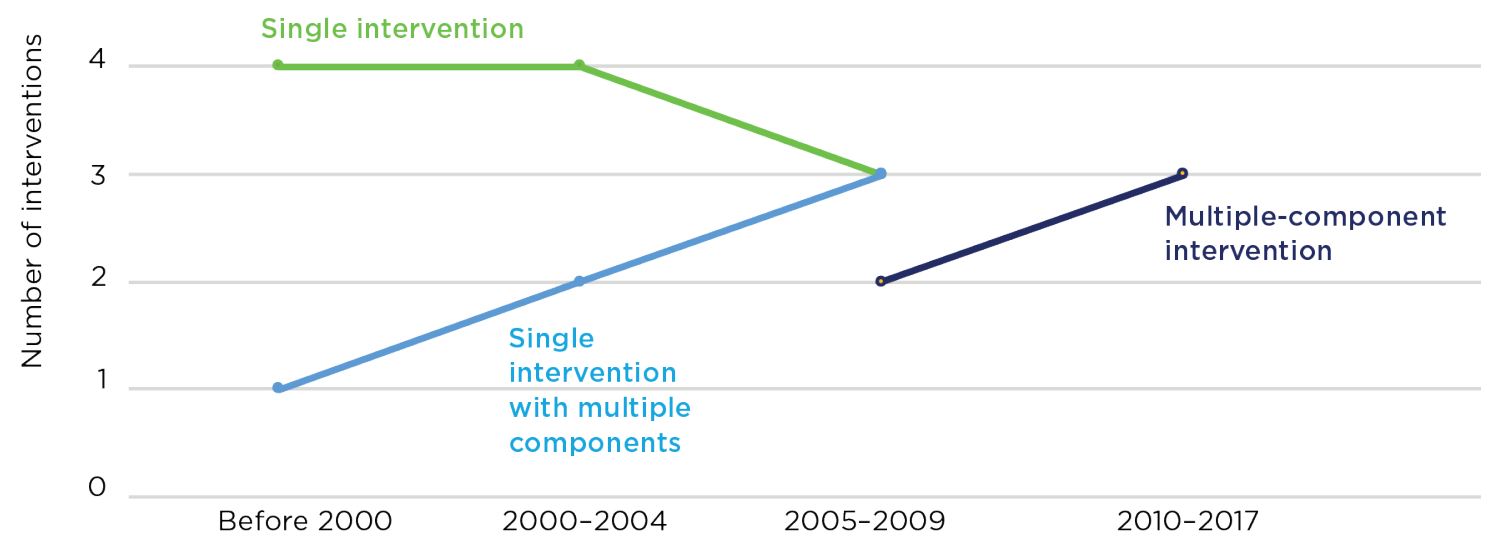

NOTE: A single intervention has a single component that was implemented and evaluated against a control arm. A single intervention with multiple components is composed of multiple components with the intervention evaluated as a whole compared to a control arm. The individual components were not evaluated separately. A multiple-component intervention consists of multiple components with each component implemented and evaluated separately against a control arm.

\section{TYPES OF APPROACHES}

Several different approaches have been used to reduce child marriage. These approaches can be grouped into four categories: empowerment, community, schooling, and economic.

1. Empowerment. Empowerment approaches focus on strategies that give girls the information, skills, and support structures they need to advocate for themselves and improve their own status and well-being. In contrast to the other categories, this category contains the broadest range of approaches, including not only life-skills training, livelihoods training, and gender-rights awareness training, but also exposure to future careers, reproductive health training, and social mobilization and group formation by adult female mentors.

2. Community. Community approaches recognize that the elimination of child marriage involves not only the parents and family members of girls, but also the communities in which they live. In contrast to empowerment, schooling, and economic approaches, which directly affect intervention participants, community approaches consist of activities that are targeted toward the communities of intervention participants. This approach aims to influence community attitudes toward child marriage and increase local knowledge of the negative consequences of this harmful practice. Community dialogue and street theater are examples of this approach. 
3. Schooling. Schooling approaches focus on providing incentives to keep girls in school and for out-of-school girls to return to school. They include the provision of free school supplies and/or uniforms, payment of school fees, and tutoring in mathematics and English.

4. Economic. Economic approaches involve providing families economic incentives or opportunities to offset the costs of raising girls and to discourage them from marrying girls off. Economic approaches mainly involve cash or asset transfers that are unconditional or conditional on certain conditions being met, such as school attendance.

Empowerment was the most popular approach, included in 14 interventions, followed by economic (10 interventions), schooling (7 interventions), and community (6 interventions) approaches (Figure 2). Eleven interventions focused on a single approach: empowerment (5), schooling (3), or economic (3). Eight interventions incorporated 2 approaches, 7 of which included an empowerment approach. Two interventions utilized 3 approaches and 1 intervention incorporated all 4 approaches.

\section{ASSESSING THE SUCCESS OF INTERVENTIONS}

Classifying interventions as successful or unsuccessful was challenging because many of the interventions consisted of multiple components that were not evaluated separately. For example, Oportunidades (now called Prospera) consisted of two components: 1) conditional cash transfer and 2) provision of sexual and reproductive health education and services. ${ }^{20}$ Although the evaluation of this program concluded that it successfully reduced child marriage, it is unknown whether one or both components were key to this reduction. ${ }^{21}$ Therefore, we classified interventions into the following categories:

- Successful: All components reduced child marriage among the study population. If a single intervention with multiple components reduced child marriage, then it was also categorized as successful.

- Mixed success: One or more (but not all) components of an intervention reduced child marriage OR child marriage was reduced among one or more (but not all) subgroups (e.g., in-school girls, out-of-school girls, rural girls, urban girls). For example, only the community dialogue arm of Musoden Wasalen, implemented in Burkina Faso, reduced child marriage; schooling promotion had no effect and conditional asset transfers actually increased the risk of child marriage.

- Unsuccessful: The intervention failed to show any success in reducing child marriage. 
FIGURE 2. INTERVENTIONS AND APPROACHES USED TO REDUCE CHILD MARRIAGE BY SUCCESS STATUS AND YEAR OF IMPLEMENTATION

\begin{tabular}{|c|c|c|c|c|}
\hline & Before 2000 & $2000-2004$ & 2005-2009 & $2010-2017$ \\
\hline \multirow{4}{*}{ Successful } & Bangladesh ${ }^{26}$ & India $a^{30}$ & Bangladesh ${ }^{33}$ & Bangladesh 39 \\
\hline & Bangladesh ${ }^{27}$ & India ${ }^{31}$ & Uganda ${ }^{23}$ & \\
\hline & Colombia 22 & Mexico ${ }^{31}$ & Zimbabwe $e^{34}$ & \\
\hline & India ${ }^{28}$ & & & \\
\hline \multirow{2}{*}{ Mixed success } & Nepal ${ }^{29}$ & Ethiopia ${ }^{18}$ & Kenya ${ }^{35}$ & Burkina Faso ${ }^{24}$ \\
\hline & & & Malawi ${ }^{36}$ & Tanzania ${ }^{25}$ \\
\hline \multirow{3}{*}{ Unsuccessful } & & Bangladesh ${ }^{19}$ & India ${ }^{21}$ & \\
\hline & & Pakistan 32 & Kenya $^{37}$ & \\
\hline & & & Tanzania ${ }^{38}$ & \\
\hline
\end{tabular}

Approach

Community

Economic

Empowerment

Schooling

NOTE: Success status measures whether one or more components of an intervention successfully reduced early marriage according to the definition used in the study. Superscripts cite interventions listed in References.

Figure 2 shows the success status of interventions according to the definition used in this review. Of the 22 studies, 11 were classified as successful, 6 as mixed success, and 5 as unsuccessful. Eight of the 11 successful interventions utilized an empowerment approach, 4 of which used it as the only approach.

Of the 6 interventions classified as mixed success, 4 utilized multiple approaches and 2 used only 1 approach. The 5 interventions found to be unsuccessful in reducing child marriage were implemented in Bangladesh, India, Kenya, Pakistan, and Tanzania. Three of the 5 unsuccessful interventions utilized an economic approach (e.g., conditional cash transfer, unconditional cash transfer, microfinance), and in two of these studies, it was the sole approach.

Figure 3 presents the percentage distribution of approaches by success status of child-marriage intervention.

- Empowerment was the most utilized approach, included in 14 interventions, and had the highest success rate (57\%).

- Community was the least utilized approach, incorporated in only 6 interventions. Four of these interventions demonstrated mixed success, 1 was successful, and 1 was unsuccessful. 
FIGURE 3. PERCENTAGE DISTRIBUTION OF APPROACHES BY SUCCESS STATUS OF CHILD-MARRIAGE INTERVENTION

Community $(n=6)$

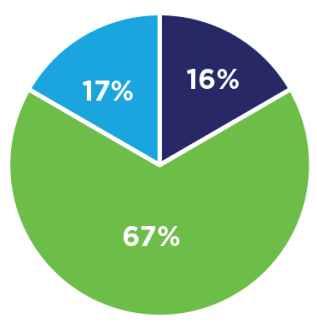

Economic $(n=10)$

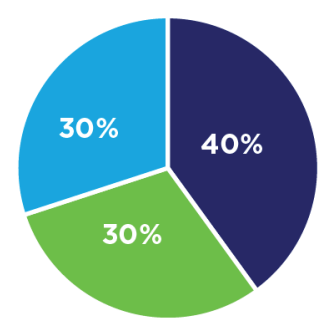

Empowerment $(n=14)$

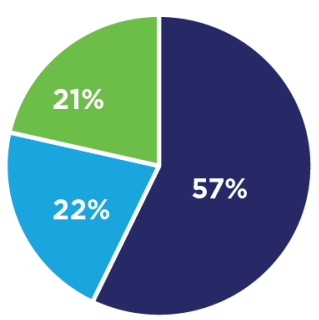

Schooling $(n=7)$

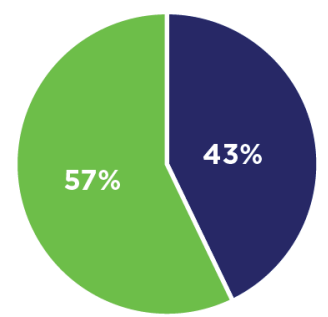

Successful

Mixed success

Unsuccessful

- Schooling was included in 7 interventions and was the second most successful approach (43\%); the remaining interventions had mixed success and none were classified as unsuccessful. The economic approach, utilized in 10 interventions, was the least successful approach: $30 \%$ failed to reduce child marriage. Economic approaches had the highest failure rate (67\%) when used as the sole approach. Interventions that coupled it with another approach had a higher success rate (57\%).

\section{POSITIVE EFFECTS ON OTHER ASPECTS OF GIRLS' WELL-BEING}

Most of the studies, except 2, examined the effect of interventions on domains other than child marriage. Fourteen interventions examined the impact on girls' schooling, including school attendance, retention, and attainment. In 12 of these studies, interventions were found to benefit girls' schooling. Eleven studies investigated the impact of interventions on pregnancy or childbearing. Nine of these studies observed that girls in the intervention group were less likely to become pregnant or experience childbearing compared to girls in the control group.

\section{INTERVENTION COSTS}

Only four studies included information about intervention costs. These four studies, implemented in Burkina Faso, Colombia, Tanzania, and Uganda, reported cost per girl to carry out their respective interventions. ${ }^{22-25}$ Two of the studies (Burkina Faso and Tanzania) went one step further by presenting information on the cost-effectiveness of the successful intervention components. The evaluation of Musoden Wasalen, which was implemented in Burkina Faso, found that the community dialogue component cost \$159 per marriage averted among girls aged 15-17.24 The cost was much higher in Tanzania, where the conditional asset transfer component cost $\$ 732$ per marriage averted among girls of the same age range. ${ }^{25}$ 


\section{DISCUSSION}

The present review examined the global state of evidence on interventions to prevent child marriage. We focused exclusively on rigorously evaluated interventions, and, as opposed to prior reviews, included new results. Over the past 20 years, an important shift has taken place in the types of interventions implemented, from single interventions with one or more components to multiplecomponent interventions. This shift likely reflects awareness of the need to pinpoint which component(s) are effective at reducing child marriage and recognition that more than one approach may be needed.

The most popular approach is empowerment, followed by economic, schooling, and community approaches. Eleven studies were classified as successful: 6 as mixed success, and 5 as unsuccessful. Empowerment was the most successful approach, while economic was the least successful. Ambiguity exists concerning the effectiveness of community and schooling approaches.

Most of the studies examined the effect of interventions on girls' schooling and pregnancy/childbearing outcomes. In most cases, interventions improved schooling outcomes and lowered the risk of pregnancy/childbearing. Very few studies reported the costs of implementing their respective interventions. This information is necessary to measure the costs of adopting interventions for future implementation.

Over the past five years, four studies have reviewed the state of evidence on what works to prevent child marriage. ${ }^{14-17}$ Our finding that empowerment is the most promising approach for reducing child marriage echoes conclusions reached in two prior studies. ${ }^{14,17}$

In contrast, the other two studies showed economic approaches to be the most effective. ${ }^{15,16}$ Our study found this approach to be the least successful. Our findings may differ from those of previous studies because different inclusion criteria and standards for measuring the effectiveness of interventions were used. Our study focused on rigorously evaluated interventions (RCTs, quasi-experimental studies, and natural experiments) that measured behavioral change (i.e., change in childmarriage prevalence or age at first marriage). Several prior reviews, in contrast, considered changes in knowledge and/or attitudes about child marriage in addition to behavioral change.

Moreover, we took a more conservative approach in assessing the effectiveness of child-marriage interventions. Rather than assessing interventions as successful if they reduced child marriage among one or more (but not all) subgroups or if one or more components (but not all) was effective, we classified these interventions as having mixed success. Thus, according to our definition, the success of some interventions may have been overestimated in previous studies. 


\section{LIMITATIONS}

This review contains several limitations that are worth mentioning.

1. We included peer-reviewed and non-peer-reviewed published studies of interventions that were evaluated as part of RCTs, quasi-experimental studies, and natural experiments. Thus, conclusions reached about the types of interventions that work to prevent child marriage are biased toward findings from these studies. Evaluations of unsuccessful interventions may not have been published or documented, and thus not included in this review.

2. For some studies, we had difficulty assessing whether an intervention worked because the report contained limited information on the study's findings and/ or how the intervention was evaluated.

3. Interventions are increasingly comprised of multiple components involving one or more approaches. This movement toward interventions with multiple components has not always been accompanied by evaluations of the individual components, making it difficult to assess whether an intervention succeeded because of a particular component or the combination of multiple components.

4. Some interventions included components that could be classified as belonging to more than one approach. For example, payment of school fees could be considered both a schooling and an economic approach. The classifications we used could impact the interpretation of findings.

5. Very few studies mentioned how well the interventions were implemented (e.g., girls' participation in life-skills and livelihoods-skills training, attendance at community events, quality of youth-friendly services). Poorly implemented interventions could have impacted effectiveness at reducing child marriage. 
Incorporate an empowerment approach in the design of child-marriage interventions.

Our review, as well as two prior reviews, found empowerment to be the most successful approach for reducing child marriage.

Administering resources directly toward the girls themselves is more effective than approaches directed at families and communities.

Strengthen the evidence base of what works and what does not work to delay child marriage.

The current body of evidence on child-marriage interventions focuses on successful interventions. Greater transparency and better documentation of interventions that did not work is needed to prevent resources from being wasted on ineffective interventions.

Analyze the impact of individual components of interventions to determine the most costeffective interventions.

In a context of limited financial resources, resources need to be allocated so that maximum reductions in the prevalence of child marriage is achieved.

Measure the quality and coverage of interventions when evaluating child-marriage interventions.

Poor-quality interventions or those with limited coverage can misrepresent and skew findings. Assessing quality and coverage of interventions provides additional context about how and why certain interventions work, which is useful for program implementation.
Carefully review the state of evidence on child-marriage interventions when planning an intervention.

The fact that an intervention worked (or did not work) in one setting or among a particular subgroup of girls does not necessarily mean that it will work in a different setting or among a different subgroup. Moreover, the environment in which an intervention is implemented may have affected the effectiveness of an intervention. For example, uncontrollable outside forces (e.g., economic crisis) may have had an unusual influence on intervention results. Such circumstances should be kept in mind when planning future child-marriage interventions.

Conduct more rigorous evaluations of child-marriage interventions.

In contrast to previous reviews of child-marriage interventions, this study focused exclusively on rigorously evaluated interventions (RCTs, quasiexperimental studies, natural experiments). More rigorous studies are needed to effectively assess the impact of interventions on child marriage.

Include information about the cost, including cost-effectiveness, of interventions in published studies and reports.

Cost information is needed to assess the feasibility of adopting interventions for implementation, especially in different contexts. 


\section{CONCLUSION}

Although progress has been made toward building an evidence base on what works to prevent child marriage, greater effort is needed to systematically ascertain which interventions are successful or unsuccessful in delaying child marriage and for which subgroups of girls these interventions work.

Concrete knowledge of what works to delay child marriage is needed to scale up interventions so that more girls benefit. In a context of scarce resources and competing priorities, investments in ending child marriage need to be channeled into proven and cost-effective interventions. Doing so will allow more girls to delay marriage, finish their education, and maximize their ability to contribute productively to society.

\section{REFERENCES}

1. UNICEF. 2014. Ending Child Marriage: Progress and Prospects. New York: UNICEF.

2. UNICEF. 2016. UNICEF Global Databases: Child Marriage. New York: UNICEF.

3. Blanc, A.K., W. Winfrey, and J. Ross. 2013. “New findings for maternal mortality age patterns: Aggregated results for 38 countries," PloS One 8(4): e59864.

4. Fortney, J. and K. Kiragu. 1996. "Obstetric Morbidity and Mortality,” in Howson, C.P., P.F. Harrison, D. Hotra, and M. Law (eds.) In Her Lifetime: Female Morbidity and Mortality in Sub-Saharan Africa. Washington, DC: National Academy Press.

5. Zabin, L.S. and K. Kiragu 1998. "The health consequences of adolescent sexual and fertility behavior in sub-Saharan Africa," Studies in Family Planning 29(2): 210-232.

6. Nour, N.M. 2006. “Health consequences of child marriage in Africa," Emerging Infectious Diseases 12(11): 1644

7. Santhya, K. 2011. "Early marriage and sexual and reproductive health vulnerabilities of young women: A synthesis of recent evidence from developing countries," Current Opinion in Obstetrics and Gynecology 23(5): 334-339.

8. Santhya, K., U. Ram, R. Acharya, S.J. Jejeebhoy, F. Ram, and A. Singh. 2010. "Associations between early marriage and young women's marital and reproductive health outcomes: Evidence from India," International Perspectives on Sexual and Reproductive Health 36(3): 132-139.

9. Kidman, R. 2016. "Child marriage and intimate partner violence: A comparative study of 34 countries," International Journal of Epidemiology 46(2): 662-675.

10. Wodon, Q., C. Male, A. Nayihouba, et al. 2017. Economic Impacts of Child Marriage: Global Synthesis Report. Washington, DC: The World Bank and International Center for Research on Women (ICRW)

11. Pew Research Center. "Many Countries Allow Child Marriage." September 12, 2016. http://www. pewresearch.org/fact-tank/2016/09/12/many-countries-allow-child-marriage/. Accessed September 15, 2017

12. UNFPA. 2014. State of World Population 2014: The Power of 1.8 Billion Adolescents, Youth and the Transformation of the Future. New York: UNFPA

13. Jain, S. and K. Kurz. 2007. New Insights on Preventing Child Marriage: A Global Analysis of Factors and Programs. Washington, DC: International Center for Research on Women.

14. Lee-Rife, S., A. Malhotra, A. Warner, and A.M. Glinski. 2012. "What works to prevent child marriage: A review of the evidence," Studies in Family Planning 43(4): 287-303.

15. Kalamar, A.M., S. Lee-Rife, and M.J. Hindin. 2016. “Interventions to prevent child marriage among young people in low-and middle-income countries: A systematic review of the published and gray literature," Journal of Adolescent Health 59(3): S16-S21.

16. Parsons, J. and J. McCleary-Sills. 2014. "Preventing Child Marriage: Lessons from World Bank Group Gender Impact Evaluations." Washington, DC: The World Bank. 
17. Malhotra, A., A. Warner, A. McGonagle, and S. Lee-Rife. 2011. "Solutions to End Child Marriage." Washington, DC: International Center for Research on Women.

18. Erulkar, A.S. and E. Muthengi. 2009. "Evaluation of Berhane Hewan: A program to delay child marriage in rural Ethiopia," International Perspectives on Sexual and Reproductive Health 35(1): 6-14.

19. Amin, S. 2011. “Empowering Adolescent Girls in Rural Bangladesh: Kishori Abhijan.” Promoting Healthy, Safe, and Productive Transitions to Adulthood. Brief No. 13. New York: Population Council.

20. Gulemetova-Swan, M. 2009. "Evaluating the Impact of Conditional Cash Transfer Programs on Adolescent Decisions About Marriage and Fertility: The Case of Oportunidades." PhD Thesis. Philadelphia: University of Pennsylvania.

21. Kanesathasan, A. 2008. "Catalyzing Change: Improving Youth Sexual and Reproductive Health through Disha, an Integrated Program in India." Washington DC: International Center for Research on Women.

22. Angrist, J., E. Bettinger, E. Bloom, E. King, and M. Kremer. 2002. “Vouchers for private schooling in Colombia: Evidence from a randomized natural experiment," The American Economic Review 92(5): 1535-1558

23. Bandiera, O., N. Buehren, R. Burgess, et al. 2012. "Empowering Adolescent Girls: Evidence from a Randomized Control Trial in Uganda." Washington, DC: World Bank.

24. Erulkar, A., G. Medhin, and E. Weissman. 2017. “The Impact and Cost of Child Marriage Prevention in Rural Burkina Faso." Addis Ababa: Population Council.

25. Erulkar, A., G. Medhin, and E. Weissman. 2017. "The Impact and Cost of Child Marriage Prevention in Rural Tanzania." Addis Ababa: Population Council.

26. Heath, R. and A.M. Mobarak. 2015. "Manufacturing growth and the lives of Bangladeshi women," Journal of Development Economics 115: 1-15.

27. Hahn, Y., A. Islam, K. Nuzhat, R. Smyth, and H.-S. Yang. 2015. "Education, Marriage and Fertility: Long-Term Evidence from a Female Stipend Program in Bangladesh." Department of Economics, Monash University. Discussion Paper No. 30/15.

28. Pande, R., K. Kurz, S. Walia, K. MacQuarrie, and S. Jain. 2006. “Improving the Reproductive Health of Married and Unmarried Youth in India: Evidence of Effectiveness and Costs from CommunityBased Interventions. Final Report of the Adolescent Reproductive Health Program in India."

29. Mathur, S., M. Mehta, and A. Malhotra. 2004. "Youth Reproductive Health in Nepal: Is Participation the Answer?" Washington, DC: International Center for Research on Women.

30. Rahman, M. and E.E. Daniel. 2010. "A Reproductive Health Communication Model That Helps Improve Young Women's Reproductive Life and Reduce Population Growth: The Case of PRACHAR from Bihar, India." Watertown, MA: Pathfinder International.

31. Jensen R. 2012. "Do labor market opportunities affect young women's work and family decisions? Experimental evidence from India," The Quarterly Journal of Economics 127(2): 753-792.

32. Alam, A., J.E. Baez, and X.V. Del Carpio. 2011. “Does Cash for School Influence Young Women's Behavior in the Longer Term? Evidence from Pakistan." Bonn, Germany: The Institute for the Study of Labor.

33. Shahnaz, R. and R. Karim. 2008. Providing Microfinance and Social Space to Empower Adolescent Girls: An Evaluation of Brac's ELA Centres. Dhaka, Bangladesh: BRAC Research \& Evaluation Division.

34. Hallfors, D.D., H. Cho, S. Rusakaniko, et al. 2015. "The Impact of School Subsidies on HIV-Related Outcomes among Adolescent Female Orphans," Journal of Adolescent Health 56(1): 79-84.

35. Duflo, E., P. Dupas, and M. Kremer. 2015. “Education, HIV, and early fertility: Experimental evidence from Kenya," The American Economic Review 105(9): 2757-2797.

36. Baird, S., C. McIntosh, and B. Özler. 2011. "Cash or condition? Evidence from a cash transfer experiment," The Quarterly Journal of Economics 126(4): 1709-1753.

37. Handa, S., A. Peterman, C. Huang, C. Halpern, A. Pettifor, and H. Thirumurthy. 2015. "Impact of the Kenya cash transfer for orphans and vulnerable children on early pregnancy and marriage of adolescent girls," Social Science \& Medicine 141: 36-45.

38. Buehren, N., M. Goldstein, S. Gulesci, M. Sulaiman, and V. Yam. 2015. “Evaluation of layering microfinance on an adolescent development program for girls in Tanzania." Unpublished manuscript.

39. Amin, S., J. Ahmed, J. Saha, I. Hossain, and E. Haque. 2016. “Delaying Child Marriage through Community-Based Skills-Development Programs for Girls. Results from a Randomized Controlled Study in Rural Bangladesh." New York and Dhaka, Bangladesh: Population Council. 


\section{SUCCESSFUL INTERVENTIONS}

\begin{tabular}{|c|c|c|c|c|c|c|c|c|}
\hline Country & Program/Years & Study & $\begin{array}{l}\text { Evaluation } \\
\text { design }\end{array}$ & $\begin{array}{l}\text { Type of } \\
\text { intervention }\end{array}$ & Components & $\begin{array}{l}\text { Approaches } \\
\text { used }\end{array}$ & $\begin{array}{l}\text { Other outcomes } \\
\text { examined }\end{array}$ & $\begin{array}{l}\text { Other outcomes } \\
\text { successfully impacted }\end{array}$ \\
\hline Bangladesh & $\begin{array}{l}\text { Garment factory placement, } \\
1980 \text { s-2009a }\end{array}$ & $\begin{array}{l}\text { Heath and } \\
\text { Mobarak } 2015\end{array}$ & Natural Experiment & Single & $\begin{array}{l}\text { Exposure to garment } \\
\text { industry }\end{array}$ & Empowerment & $\begin{array}{l}\text { Educational } \\
\text { attainment, enrollment, } \\
\text { childbirth }\end{array}$ & $\begin{array}{l}\text { Educational attainment, } \\
\text { enrollment, childbirth }\end{array}$ \\
\hline Bangladesh & $\begin{array}{l}\text { Female Secondary School } \\
\text { Stipend Program (FSSSP), } \\
\text { 1994-2011 }\end{array}$ & $\begin{array}{l}\text { Hahn et al. } \\
2015\end{array}$ & Natural Experiment & Single & $\begin{array}{l}\text { Free secondary } \\
\text { education and cash } \\
\text { stipend }\end{array}$ & $\begin{array}{l}\text { Schooling, } \\
\text { Economic }\end{array}$ & $\begin{array}{l}\text { Educational attain- } \\
\text { ment, secondary } \\
\text { school completion, age } \\
\text { at first birth }\end{array}$ & $\begin{array}{l}\text { Educational attainment, } \\
\text { secondary school } \\
\text { completion, age at first } \\
\text { birth }\end{array}$ \\
\hline Bangladesh & $\begin{array}{l}\text { Bangladeshi Association } \\
\text { for Life Skills, Income, and } \\
\text { Knowledge for Adolescents } \\
\text { (BALIKA), 2012-2015 }\end{array}$ & $\begin{array}{l}\text { Amin et al. } \\
2016\end{array}$ & $\begin{array}{l}\text { Randomized } \\
\text { Controlled Trial }\end{array}$ & Multiple & $\begin{array}{l}\text { 1) Education } \\
\text { 2) Gender-rights } \\
\text { awareness and training } \\
\text { 3) Livelihoods-skills } \\
\text { training }\end{array}$ & $\begin{array}{l}\text { Empowerment, } \\
\text { Schooling }\end{array}$ & Currently out of school & Currently out of school \\
\hline Bangladesh & $\begin{array}{l}\text { Employment and Livelihood } \\
\text { for Adolescents (ELA) Centers, } \\
2005-07\end{array}$ & $\begin{array}{l}\text { Shahnaz and } \\
\text { Karim } 2008\end{array}$ & $\begin{array}{l}\text { Quasi- } \\
\text { experimental }\end{array}$ & $\begin{array}{l}\text { Single with } \\
\text { multiple } \\
\text { components }\end{array}$ & $\begin{array}{l}\text { Microfinance; skill-based } \\
\text { training }\end{array}$ & $\begin{array}{l}\text { Empowerment, } \\
\text { Economic }\end{array}$ & School enrollment & None \\
\hline Colombia & $\begin{array}{l}\text { Programa de Ampliación de } \\
\text { Cobertura de la Educación } \\
\text { Secundaria (PACES), 1993- } \\
1998^{c}\end{array}$ & $\begin{array}{l}\text { Angrist et al. } \\
2002\end{array}$ & Natural Experiment & Single & $\begin{array}{l}\text { School voucher lottery } \\
\text { for private-school tuition }\end{array}$ & Schooling & $\begin{array}{l}\text { Educational } \\
\text { attainment, school } \\
\text { enrollment, pregnant } \\
\text { or has child }\end{array}$ & $\begin{array}{l}\text { Educational attainment, } \\
\text { pregnant or has child }\end{array}$ \\
\hline India & PRACHAR, 2002-05 & $\begin{array}{l}\text { Rahman and } \\
\text { Daniel } 2010\end{array}$ & Quasi-experimental & Single & $\begin{array}{l}\text { Reproductive health } \\
\text { training (individual and } \\
\text { community) }\end{array}$ & $\begin{array}{l}\text { Empowerment, } \\
\text { Community }\end{array}$ & Childbearing & Childbearing \\
\hline India & $\begin{array}{l}\text { Business process outsourcing } \\
\text { (BPO) recruiting services, } \\
\text { 2003-06 }\end{array}$ & Jensen 2012 & $\begin{array}{l}\text { Randomized } \\
\text { Controlled Trial }\end{array}$ & Single & $\begin{array}{l}\text { Three years of business } \\
\text { process outsourcing } \\
\text { (BPO) recruiting services }\end{array}$ & Empowerment & Childbearing & Childbearing \\
\hline India & $\begin{array}{l}\text { Maharashtra Life Skills } \\
\text { Program, 1998-99 }\end{array}$ & $\begin{array}{l}\text { Pande et al. } \\
2006\end{array}$ & $\begin{array}{l}\text { Randomized } \\
\text { Controlled Trial }\end{array}$ & Single & Life-skills curriculum & Empowerment & None & NA \\
\hline Mexico & $\begin{array}{l}\text { Oportunidades, } \\
2002-04\end{array}$ & $\begin{array}{l}\text { Gulemeto- } \\
\text { va-Swan } 2009\end{array}$ & Quasi-experimental & $\begin{array}{l}\text { Single with } \\
\text { multiple } \\
\text { components }\end{array}$ & $\begin{array}{l}\text { Cash transfer conditional } \\
\text { on school attendance; } \\
\text { provision of sexual and } \\
\text { reproductive health } \\
\text { education and services }\end{array}$ & $\begin{array}{l}\text { Empowerment, } \\
\text { Economic }\end{array}$ & Childbearing & None \\
\hline Uganda & $\begin{array}{l}\text { Empowerment and Livelihood } \\
\text { for Adolescents (ELA) Centers, } \\
2008-10\end{array}$ & $\begin{array}{l}\text { Bandiera et al. } \\
2012\end{array}$ & $\begin{array}{l}\text { Randomized } \\
\text { Controlled Trial }\end{array}$ & $\begin{array}{l}\text { Single with } \\
\text { multiple } \\
\text { components }\end{array}$ & $\begin{array}{l}\text { Life-skills training; } \\
\text { vocational-skills training }\end{array}$ & Empowerment & Childbearing & Childbearing \\
\hline Zimbabwe & $\begin{array}{l}\text { HIV prevention intervention, } \\
2007-10\end{array}$ & $\begin{array}{l}\text { Hallfors et al. } \\
2015\end{array}$ & $\begin{array}{l}\text { Randomized } \\
\text { Controlled Trial }\end{array}$ & Single & $\begin{array}{l}\text { School fees, uniforms, } \\
\text { and school supplies }\end{array}$ & Schooling & $\begin{array}{l}\text { School dropout, years } \\
\text { of schooling }\end{array}$ & $\begin{array}{l}\text { School dropout, years } \\
\text { of schooling }\end{array}$ \\
\hline
\end{tabular}

NA = Not applicable

a This was a natural experiment. Start date represents approximate date when garment factories opened near sample villages. Some variation in the start date exists by village.

b This was a natural experiment. End date represents the year of evaluation.

c This was a natural experiment. End date represents the year of evaluation. 


\section{MIXED SUCCESS INTERVENTIONS}

\begin{tabular}{|c|c|c|c|c|c|c|c|c|}
\hline Country & Program/Years & Study & $\begin{array}{l}\text { Evaluation } \\
\text { design }\end{array}$ & $\begin{array}{l}\text { Type of } \\
\text { intervention }\end{array}$ & Components & $\begin{array}{l}\text { Approaches } \\
\text { used }\end{array}$ & $\begin{array}{l}\text { Other outcomes } \\
\text { examined }\end{array}$ & $\begin{array}{l}\text { Other outcomes } \\
\text { successfully impacted }\end{array}$ \\
\hline Burkina Faso & Musoden Wasalen & $\begin{array}{l}\text { Erulkar et al. } \\
2017\end{array}$ & Quasi-experimental & Multiple & $\begin{array}{l}\text { 1) Community dialogue } \\
\text { 2) Schooling promotion } \\
\text { 3) Conditional asset } \\
\text { transfer } \\
\text { 4) Full model: } \\
\text { Community dialogue }+ \\
\text { schooling promotion }+ \\
\text { conditional asset transfer }\end{array}$ & $\begin{array}{l}\text { Community, } \\
\text { Schooling, } \\
\text { Economic }\end{array}$ & School attendance & School attendance \\
\hline Ethiopia & Berhane Hewan & $\begin{array}{l}\text { Erulkar and } \\
\text { Muthengi } \\
2009\end{array}$ & Quasi-experimental & $\begin{array}{l}\text { Single with } \\
\text { multiple } \\
\text { components }\end{array}$ & $\begin{array}{l}\text { Social mobilization and } \\
\text { group formation by } \\
\text { adult female mentors; } \\
\text { participation in nonformal } \\
\text { education and livelihoods } \\
\text { training for out-of-school } \\
\text { girls or support to remain } \\
\text { in school; community } \\
\text { conversations }\end{array}$ & $\begin{array}{l}\text { Empowerment, } \\
\text { Community, } \\
\text { Schooling }\end{array}$ & School enrollment & School enrollment \\
\hline Kenya & $\begin{array}{l}\text { Education Subsidy and HIV } \\
\text { Education, 2003-05 }\end{array}$ & $\begin{array}{l}\text { Duflo et al. } \\
2015\end{array}$ & $\begin{array}{l}\text { Randomized } \\
\text { Controlled Trial }\end{array}$ & Multiple & $\begin{array}{l}\text { Provision of school } \\
\text { uniforms; teacher HIV } \\
\text { training program }\end{array}$ & Schooling & $\begin{array}{l}\text { Attendance rate, ever } \\
\text { pregnant }\end{array}$ & Ever pregnant \\
\hline Malawi & $\begin{array}{l}\text { Zomba Cash Transfer Program, } \\
\text { 2007-09 }\end{array}$ & $\begin{array}{l}\text { Baird et al. } \\
2011\end{array}$ & $\begin{array}{l}\text { Randomized } \\
\text { Controlled Trial }\end{array}$ & Single & $\begin{array}{l}\text { Conditional cash transfer } \\
\text { (enroll in school) }\end{array}$ & Economic & $\begin{array}{l}\text { School enrollment, } \\
\text { pregnancy }\end{array}$ & $\begin{array}{l}\text { School enrollment, } \\
\text { pregnancy }\end{array}$ \\
\hline Nepal & $\begin{array}{l}\text { Adolescent Participatory } \\
\text { Project, 1998-2003 }\end{array}$ & $\begin{array}{l}\text { Mathur et al. } \\
2004\end{array}$ & Quasi-experimental & $\begin{array}{l}\text { Single with } \\
\text { multiple } \\
\text { components }\end{array}$ & $\begin{array}{l}\text { Adolescent-friendly ser- } \\
\text { vices; peer education and } \\
\text { counseling; information } \\
\text { and education campaign; } \\
\text { adult peer education; } \\
\text { youth clubs and street } \\
\text { theater on social norms; } \\
\text { efforts to improve } \\
\text { livelihood opportunities; } \\
\text { teacher training }\end{array}$ & $\begin{array}{l}\text { Empowerment, } \\
\text { Community }\end{array}$ & $\begin{array}{l}\text { Completed Grade } 6 \text { or } \\
\text { higher }\end{array}$ & $\begin{array}{l}\text { Completed Grade } 6 \text { or } \\
\text { higher }\end{array}$ \\
\hline Tanzania & Nemeesha & $\begin{array}{l}\text { Erulkar et al. } \\
2017\end{array}$ & Quasi-experimental & Multiple & $\begin{array}{l}\text { 1) Community dialogue } \\
\text { 2) Schooling promotion } \\
\text { 3) Conditional asset } \\
\text { transfer } \\
\text { 4) Full model: } \\
\text { Community dialogue }+ \\
\text { schooling promotion }+ \\
\text { conditional asset transfer }\end{array}$ & $\begin{array}{l}\text { Empowerment, } \\
\text { Community, } \\
\text { Schooling, } \\
\text { Economic }\end{array}$ & School attendance & School attendance \\
\hline
\end{tabular}




\section{UNSUCCESSFUL INTERVENTIONS}

\begin{tabular}{|c|c|c|c|c|c|c|c|c|}
\hline Country & Program/Years & Study & $\begin{array}{l}\text { Evaluation } \\
\text { design }\end{array}$ & $\begin{array}{l}\text { Type of } \\
\text { intervention }\end{array}$ & Components & $\begin{array}{l}\text { Approaches } \\
\text { used }\end{array}$ & $\begin{array}{l}\text { Other outcomes } \\
\text { examined }\end{array}$ & $\begin{array}{l}\text { Other outcomes } \\
\text { successfully impacted }\end{array}$ \\
\hline Bangladesh & Kishori Abhijan, 2001-03 & Amin 2011 & Quasi-experimental & Single & $\begin{array}{l}\text { Life-skills training; } \\
\text { livelihoods training }\end{array}$ & Empowerment & School dropout & None \\
\hline India & $\begin{array}{l}\text { Development Initiative } \\
\text { Supporting Healthy } \\
\text { Adolescents (DISHA), } \\
2005-07\end{array}$ & $\begin{array}{l}\text { Kanesathasan } \\
\text { et al. } 2008\end{array}$ & Quasi-experimental & $\begin{array}{l}\text { Single with } \\
\text { multiple } \\
\text { components }\end{array}$ & $\begin{array}{l}\text { Youth groups; peer } \\
\text { education; livelihoods } \\
\text { training; community } \\
\text { entry and mobilization; } \\
\text { adult groups and youth- } \\
\text { adult partnership groups; } \\
\text { youth-friendly services }\end{array}$ & $\begin{array}{l}\text { Empowerment, } \\
\text { Community }\end{array}$ & None & NA \\
\hline Kenya & CT-OVT, 2007-11 & $\begin{array}{l}\text { Handa et al. } \\
2015\end{array}$ & $\begin{array}{l}\text { Randomized } \\
\text { Controlled Trial }\end{array}$ & Single & $\begin{array}{l}\text { Unconditional cash } \\
\text { transfer }\end{array}$ & Economic & Pregnancy & Pregnancy \\
\hline Pakistan & $\begin{array}{l}\text { Punjab Female School Stipend } \\
\text { Program, 2003-09d }\end{array}$ & Alam et al. 2011 & Natural experiment & Single & $\begin{array}{l}\text { Conditional cash transfer } \\
\text { contingent on school } \\
\text { attendance }\end{array}$ & Economic & $\begin{array}{l}\text { School enrollment, } \\
\text { childbearing }\end{array}$ & School enrollment \\
\hline Tanzania & $\begin{array}{l}\text { Empowerment and Livelihood } \\
\text { for Adolescents (ELA) Centers, } \\
2009-11\end{array}$ & $\begin{array}{l}\text { Buehren et al. } \\
2015\end{array}$ & $\begin{array}{l}\text { Randomized } \\
\text { Controlled Trial }\end{array}$ & Multiple & $\begin{array}{l}\text { 1) Vocational and } \\
\text { life-skills training } \\
\text { 2) Vocational and } \\
\text { life-skills training + } \\
\text { microfinance }\end{array}$ & $\begin{array}{l}\text { Empowerment, } \\
\text { Economic }\end{array}$ & Pregnancy & None \\
\hline
\end{tabular}

NA $=$ Not applicable

d This was a natural experiment. End date represents year of evaluation. 